\title{
Controversies and Common Ground in Wild and Domestic Fine Fiber Production in Argentina
}

\author{
Julieta von Thungen*, Elisa Martin and Maria Rosa Lanari \\ Instituto Nacional de Tecnología Agropecuaria, Estación Experimental Bariloche, Bariloche, Argentina
}

This work analyzes possible obstacles to developing new products or old merchandise using an innovative method. It will look into stakeholders of fine fiber and meat products from three distinctive socioecological systems. Through three case studies, we explore how natural resources management is connected to interests, values, and knowledge by stakeholders, which include government, the scientific community, and people with rural livelihoods. The government vertex is the national and provincial authorities involved with decision-makers at the national and provincial level. The Scientific-Technological vertex includes researchers from INTA, CONICET, and Universities. Rural livelihoods include livestock keepers, farmers, and local people with traditional knowledge. We will

OPEN ACCESS

Edited by:

Carol Kerven

University College London, United Kingdom

Reviewed by:

Jane Addison,

James Cook University, Australia Sandagsuren Undargaa, Independent Researcher, Vancouver, Canada

${ }^{*}$ Correspondence: Julieta von Thungen jvthungen@gmail.com

Specialty section:

This article was submitted to Agroecology and Ecosystem Services, a section of the journal Frontiers in Sustainable Food Systems

Received: 23 April 2020 Accepted: 13 January 2021 Published: 02 March 2021

Citation:

von Thungen J, Martin E and Lanari MR (2021) Controversies and

Common Ground in Wild and Domestic Fine Fiber Production in

Argentina.

Front. Sustain. Food Syst. 5:550821. doi: 10.3389/fsufs.2021.550821 address the goods and services provided by two species of wild camelids and domestic livestock. The three cases have both similarities and differences in their focus and common ground of controversial spaces. They create complex networks of relationships and bonds leading to diverse outcomes. Top-down or bottom-up experiences hold distinct epistemology and research consequences, they affect rural livelihoods in various ways. For the three rural livelihoods, meaningful regulations should be endogenous social constructions. However, there are no longitudinal studies on the trajectories of these case studies. Long-term multispecies grazing opportunities are available for the three case studies. It depends on how stakeholders identify flexibility in their common ground to enable resilience to catastrophic events.

Keywords: vicugna, creole goats, guanacos, rangeland management, rural livelihoods, development policy

\section{INTRODUCTION}

The innovation and development processes in rural arid and semi-arid environments remain complex issues. They encompass a variety of individuals, groups, and institutions as users of biodiversity. Innovations lead to controversies, tensions, conflicts, and power disputes (León and Aguiar, 1984; UNCCD, 1994; PRODESER, 1997; Hill et al., 2013; Gaitán et al., 2018; García et al., 2019).

The precautionary principle is the backbone of conservation in Latin America. This moral law is widely present in the laws applied to native species. In contrast to this principle, people with rural livelihoods execute decisions based on their previous experience when they consider some native or exotic species as a pest or nuisance. These differences are usually rooted within interests, values, and knowledge of stakeholders (Petitpas and Bonacic, 2019). All actors seem to assign an interest in biodiversity, yet they may not share a common ground. Thus, Controversies among scientists' research approaches and epistemology often develop conflicts and obstacles when these 
results are applied into biodiversity management decisions, which are crucial for ensuring future human well-being (Quiroga Mendiola, 2013; Easdale et al., 2019; Oliva et al., 2019; Marino et al., 2020).

Vicugna (Vicugna vicugna) and guanaco (Lama guanicoe) are two closely related wild South American camelids, emblematic to the Andean region. Both species have been described at some point as being on the brink of extinction. For this reason, they were entered, respectively, as Appendices I and II of CITES (Bolcovik and Ramadori, 2006). These two wild species coexist with the domesticated alpaca and llamas. The characterization of genetic resources in domestic and native animal populations is a step toward their conservation and protection.

One of the most powerful drivers of genetic erosion and associated losses of diversity is the overvaluation and excessive use of transboundary breeds over local breeds (FAO, 2007) and habitat fragmentation (Lacy, 1992). Productivity is associated with transboundary commercial breeds and thereby ignoring genotype-environment interactions. This is adequate for hegemonic discourse (Quiroga Mendiola, 2013) or in other words, to the canonization and overvaluation of western science (Fairweather, 2010; Fairweather and Hunt, 2011; Easdale and Domptail, 2014; Easdale and Aguiar, 2018; Kuhlmann and Rip, 2019). Rural livelihoods value their wildlife and local breeds, of traditional and low input systems. However, they find resistance and rejection, describing them as primitive and inefficient by scientists and decision makers. Controversies among the scientific community affect livelihoods, touching the interests and underlying values of all stakeholder groups.

This work analyzes possible obstacles to develop innovative products or old merchandise by a novel method. It will look into the actors of fine fiber production and meat in three distinctive socioecological systems. Identifying large clusters of institutional actors (vertex), controversies, and possible conflicts within and among groups may simplify the development process of special animal fiber production.

\section{APPROACH}

\section{Framework for Stakeholders}

Countries maintain various institutional arrangements involving government, universities, and industries to develop scientific and technological transformation. Different political histories and traditions create alternative models of innovation systems. Knowledge production and science policy has been discussed through models like the Sabato-Botana Triangle (Sábato, 1975), Triple Helix (Etzkowitz and Leydesdorff, 2000), and Next Generation (Kuhlmann and Rip, 2019). In the agricultural context, Vanclay et al. (2006) analyzed knowledge production from individual farmers' points of view to repertoires for social construction. To analyze collective "common ground" within government, the science community, and rural livelihoods, we identified stakeholders involved in three grazing systems in the context of natural resources Table 1. We describe their roles to show controls, tensions, and communications pathways in Figure 1.

One vertex of this triangle is the governmental decisionmaking agencies at the national and provincial level. The second vertex is the scientific and academic knowledge sector, and the third is the rural livelihoods and their commercial organization.

Argentina has a Federal government with 23 provinces, which have full autonomy, as a part of the Nation. The provinces are self-governing, draw up their constitutions, executive, law, and judicial powers, including their own security forces. The national constitution grants the provinces the rights over their natural resources. However, the nation has overall general laws and is responsible for international relations through the various conventions.

The enforcement of natural resources laws is under two different ministries at the national level. The Ministry of Environment and Sustainable Development (MADS) is the enforcement authority for the Convention on Trade International of Endangered Species of Wild Fauna and Flora (CITES) and the Convention of Biodiversity (CBD), including the Nagoya Protocol and the Action Plan against Land Degradation and Drought (PAN, Law $\mathrm{N}^{\circ}$ 24971). National Law $\mathrm{N}^{\circ} 22.421$ on Wildlife Conservation was passed in 1981, after the first CITES convention in 1980 in response to international conservation concern.

The Ministry of Agriculture, Livestock, Fishing and Food (MAGyP) is the enforcement authority of National Law $\mathrm{N}^{\circ}$ 25.422/01 for "The recovery of sheep husbandry in Patagonia," and "Regime for the recovery, promotion and development of the goat breeding activity," Law $\mathrm{N}^{\circ}$ 26141/06. Relevant to the case studies here is the Ministry of Justice and Human Rights, which enforces the Law of Indigenous Communities (Law $\mathrm{N}^{\circ}$ 23302). Linking this last law and CBD, the Nagoya protocol (2010) promotes and safeguards the fair and equitable benefit sharing derived from utilizing genetic resources (Swiderska et al., 2012). Article 12 opens new communication practices, community protocols and knowledge dialogue. This involves different agencies within national and provincial organizations.

These three ministries of the national government establish general goals related to accounting for sustainability of natural resources jointly with social components. They have clients with diverse needs. The laws are instruments that offer budgets for programs interplaying priorities imposed by international conventions and internal policies, which are enforced by independent institutions. The provinces emulate the national governmental organization, creating an intricate communications network of power relations and exchanges.

The Scientific-Technological vertex is the Instituto Nacional de Tecnologia Agropecuaria (INTA) which depends on MAGyP, the Consejo Nacional de Investigaciones Científicas y Técnicas (CONICET) that is subordinate to the Ministry of Science, Technology, and Innovation. Public and private Universities rest on the Ministry of Education.

The rural livelihoods vertex comprises farmers, diverse aboriginal communities, livestock keepers and families, grazing their animals in various arid and semi-arid environments. They provide new merchandise or old goods by new methods or traditional knowledge. 
TABLE 1 | Summary of case studies.

\begin{tabular}{|c|c|c|c|c|}
\hline & & Vicugna & Creole Goats & Sheep - Guanacos \\
\hline \multirow[t]{3}{*}{ Stakeholders } & G & $\begin{array}{l}\text { MADS: Ministry of Environment } \\
\text { (national and provincial) } \\
\text { MAGyP: Ministry of Agriculture (national } \\
\text { and provincial) }\end{array}$ & $\begin{array}{l}\text { MAGyP: Ministry of Agriculture } \\
\text { (national and provincial) }\end{array}$ & $\begin{array}{l}\text { MADS: Ministry of Environment } \\
\text { (national and provincial) } \\
\text { MAGyP: Ministry of Agriculture } \\
\text { (national and provincial) } \\
\text { CAP Consejo Agrario Provincial }\end{array}$ \\
\hline & $\mathrm{R}$ & $\begin{array}{l}\text { INTA: Instituto Nacional de Tecnología } \\
\text { Agropecuaria } \\
\text { CONICET: Consejo Nacional de } \\
\text { Investigaciones Científicas y Técnicas, } \\
\text { National University of Jujuy } \\
\text { VICAM: Vicuñas Camélidos y Ambiente }\end{array}$ & $\begin{array}{l}\text { INTA: Instituto Nacional de Tecnología } \\
\text { Agropecuaria } \\
\text { CONICET: Consejo Nacional de } \\
\text { Investigaciones Científicas y Técnicas, } \\
\text { Catholic University of Córdoba }\end{array}$ & $\begin{array}{l}\text { INTA: Instituto Nacional de Tecnología } \\
\text { Agropecuaria } \\
\text { CONICET: Consejo Nacional de } \\
\text { Investigaciones Científicas y Técnicas, } \\
\text { CAP Consejo Agrario Provincial }\end{array}$ \\
\hline & $R L$ & Aboriginal Communities & Transhumant rural livelihoods & Sheep herders \\
\hline Focus of Controversy & $\mathrm{R}$ & $\begin{array}{l}\text { Captive breeding vs. } \\
\text { Capture-shearing-release } \\
\text { Genetic bottleneck }\end{array}$ & $\begin{array}{l}\text { High productive breeds vs. } \\
\text { environmentally adapted local breeds }\end{array}$ & $\begin{array}{l}\text { Multispecies grazing vs. land sparing } \\
\text { for guanacos }\end{array}$ \\
\hline
\end{tabular}

G, Government; R, Researchers; RL, Rural livelihoods.

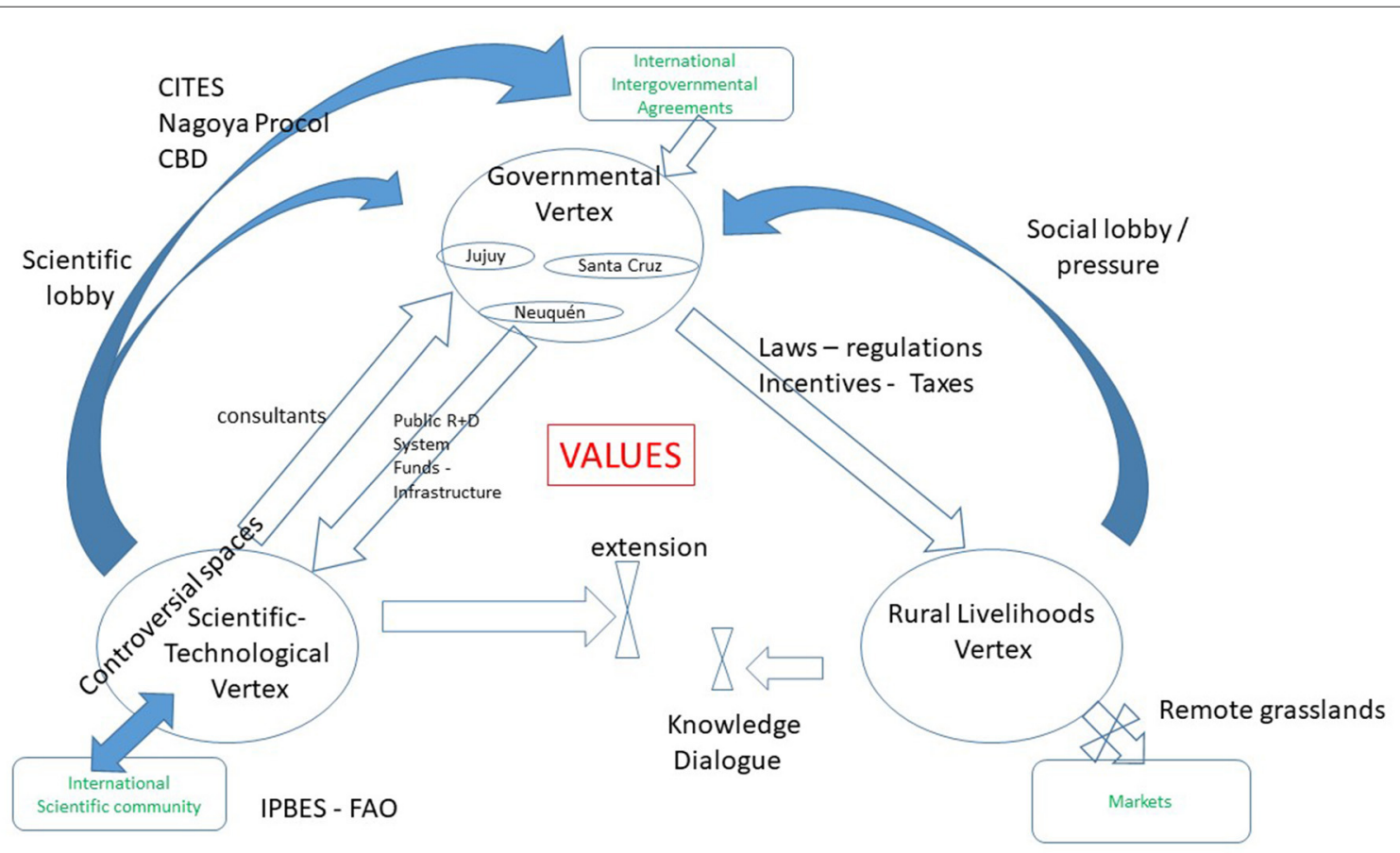

FIGURE 1 | Framework for control tensions and communication pathways.

\section{Controversial Spaces: Focus and Common Ground}

Nudler (2004), analyzes controversial spaces in science. According to him, these spaces possess two structural properties: focus and common ground. The "focus" of a controversial space represents its visible region, the tip of an iceberg. The set of visible issues is subject to controversy, discussions, and disagreements.
The "common ground" is the underwater portion of the iceberg, invisible to the participants involved in a controversy, and not part of the discussion. The concept of "common ground" synthesizes the set of elements shared and not problematized at any given time (Nudler, 2004; Rodriguez Zoya and Rodriguez Zoya, 2014). According to Nudler (2004), these controversial spaces allow science to evolve. However, this underlying region 
holds most of the values of societies (i.e., beliefs, concepts of nature, political inclinations, self, and trust). Understanding "common ground" is meaningful for management decisions, which may result in changes of livelihoods.

Controversial spaces are typical to scientific communities (Table 1). Disciplines share a common ground with a set of theories, research traditions, and accumulating knowledge leads to scientific technological progress. They discuss their controversies through experiments, data, and debate in a globalized community. These spaces share an established form of communication through publications and the peer review process, by way of which they develop. The domain of their controversial spaces is not necessarily material. In the scientific literature, common ground has different meanings and is used in various ways in diverse contexts. The term is usually understood as shared interests. At this stage, we define common grounds as a set of shared beliefs, values, traditions, art, and emotions. This aspect represents the underwater section of the iceberg, deeply rooted and substantial to existence and the social belonging of researchers.

For example, overgrazing has been the focus of controversy for over 40 years (Bisigato and Bertiller, 1997; Mazzonia and Vazquez, 2009; Gaitán et al., 2018). Recently, Oliva et al. (2019) and Marino et al. (2020) focus on the causes of land degradation is centered on complex socio-ecological drivers. However, many scientists hold overgrazing as the primary cause of biodiversity loss (Table 1).

A conflict can be defined as a relation between two or more in opposition, who may or may not be violent, based on differences in needs, interests, and goals. These differences can be real or perceived. Conflict may arise when at least one of the parties is perceived to assert its concerns at the expense of another group's interests. Controversies being at the tip of the iceberg are readily visualized and discussed. On the other side, conflicts lying deeply underwater are usually not discussed or solved, yet they can be managed.

Government communities are a diverse set of people as reflected by an average of 599 provincial and 34 national parties between 2009 and 2019. Participants remain in their positions according to the duration of the government administration. These communities resolve their disputes through lobbying and communication strategies to obtain or remain in power. Rural livelihoods may become the battlefield of the scientific controversial space or conflicts. Conflicts may arise frequently, especially with the local authorities, as their access to decisionmaking levels is infrequent.

The role of the state in Argentina is frequently under debate. Political parties in government are still a major driving force in research and innovation. The government vertex will include the national and provincial level of authorities involved with decision-making of the cases. The Scientific-Technological Vertex will include INTA, CONICET and the Universities that have researchers related to the cases. Rural livelihoods will contain livestock keepers, farmers, and local actors with traditional knowledge (Figure 1). In this paper, we will address the goods provided by two species of wild camelids and domestic livestock.
A bibliographic and existing document review was done for the three cases. Information about laws, values and interests was reviewed emphasizing the search of focus and common ground of actors involved. Available data on the strategies of intervention used in the case studies were compared. Authors have also been in contact with the case studies for about two decades, either as participants or outside observers.

\section{Case Study Sites}

The three case studies selected are representative of arid and semi-arid environments in Argentina. They share overgrazing, desertification, loss of biodiversity, and cultural erosion problems. Researchers assign overgrazing as the major production difficulty (Noy-Meir, 1973; UNCCD, 1994; Mazzonia and Vazquez, 2009; Quiroga Mendiola, 2013; Gaitán et al., 2018; Lecuyer et al., 2018). Landscape degradation affects rural livelihoods and is currently recognized as a complex socioecological problem involving desertification and climate change. Aridity and overgrazing have convergent effects on the structure and processes of ecosystems, affecting species richness, abundance of palatable grasses, and soil functioning. Recent research suggests that grazing management should aim to improve species richness and palatable species, to mitigate adverse effects of future increases in aridity on dry lands (Orr et al., 2017; Gaitán et al., 2018; Oliva et al., 2019).

The controversial spaces will be explored within the scientific vertex and the conflicts and tensions between the actors in three different cases as new knowledge evolves into decisionmaking (Figure 1). These case studies center on current conflicts revolving around vicugnas (Vicugna vicugna) in the Puna of Jujuy; transhumant creole goats in the high mountains of Neuquén; and wool sheep-guanacos (Lama guanicoe) in southern Patagonia.

The case studies set in different provinces share governmental complex organization, technological, and regional economic problems. These difficulties are related to systemic barriers in complying with the historical agro-export model based on bulk commodities originated from the pampas production region of Argentina. They have differences in land tenure, their organizational challenges, and diverse cultures.

\section{CASE STUDIES}

\section{Vicugnas in the Puna, Province of Jujuy}

People in the Puna are mostly aboriginal from kolla, quechua, and omaguaca etnias, closely related to the Andean ayllu and "Customs. "They value" making and deciding among all," linked to agricultural production (Cowan Ros and Nussbaumer, 2013). Culturally, grazing areas are community owned, although some villages are allocated for each family. The Law for Indigenous Communities (Law $\mathrm{N}^{\circ}$ 23302) surveyed 21,300 aborigines in the rural departments of Yavi and Santa Catalina (INDEC, 2010). This law allows them to gain identity and visibility in terms of their cultural civil rights. In order to obtain rights over the land they have used for centuries and now belongs to them, they have to bond as a community. However, the definition of community 
within the scope of the law is rarely aligned with the local cultural concept (Borghini, 2010; Cowan Ros and Nussbaumer, 2013).

The aboriginal people in the Puna hold mixed flocks of sheep, llamas, donkeys, and goats (INDEC, 2010). Their ancestors domesticated guanacos and vicugnas (Wheeler et al., 2006; Casey et al., 2018). They possess a deep knowledge about these species. Their weaving skill and knowledge to make a fine poncho of vicugna, was acknowledged when it passed through a wedding ring.

Vicugna management has been strongly influenced by international conservationist's pressures. By 1960, populations were at the brink of extinction in all the areas of distribution, i.e., the high Andes of northern of Argentina; Bolivia, Chile, Peru and Ecuador. Populations became isolated and underwent a genetic bottleneck (Wheeler et al., 2006). In 1975, the existing population of vicugnas was categorized in (Supplementary Material) of CITES. In 1979, countries with vicugna ratified a convention (Convenio de la Vicugna; CV), which placed conservation, population, and fiber management under strict state control. In 2009 the province of Jujuy passed the provincial Law $\mathrm{N}^{\circ}$ 5634 with a management plan for vicugna. The spirit of the plan was environmental sustainability and socio-economic development. It explicitly incorporates a Committee of eight members, four representing aboriginal communities, two from the science vertex, one from provincial government and one from national government.

In response to international restrictive policies Argentina and Peru, through their scientific-technological vertex, responded with various strategies. Argentina drove a captive breeding program in 1960 at the Experimental Station of Abra Pampa (Jujuy). The aim was to offer productive alternatives to the local communities. This experience was later multiplied in private farms inside and outside vicugna distribution range and was contested by Vicuña Camelidos y Ambiente group (VICAM) (Vila, 2002; Vila and Lichtenstein, 2006). Peru from 1973 to 1980 with German Agency for Technical Cooperation (GTZ) resources started management practices capturing, shearing, and releasing (CSR) wild vicugnas in Pampa Galeras (Peru) with the communities (Hoffmann et al., 1983). Through these experiences Hoffmann et al. (1983) realized that local communities involved in the $\mathrm{CV}$ countries are heterogeneous, with differences within and between the communities (Rendon Burgos, 2000). These experiences lead to two controversies.

The first controversy was around the genetic consequences of the captive breeding systems (Vila, 2002; Arzamendia et al., 2008). The studies on the genetic bottleneck of Peru (Wheeler et al., 2006), promoted the controversy. Two laboratories that represented opposed interests concluded that heterozygosity estimates were relatively high for captive and wild vicugna populations of Jujuy (Longo and Valdecantos, 2012; Anello et al., 2016).

The CSR experiences in the province of Jujuy started in 2003. Initially, VICAM researchers developed a top-down experience. The project emphasized teaching adequate procedures to private producers of the Puna, belonging to an Association Cieneguillas (2003-2005) and Santa Catalina Cooperative (2012, 2014) (Bonacic and Gimpel, 2003; Vilá et al., 2010). Initially the project and later reports showed that the conceptual framework was conceived as a top-down experience. The aim of the project was to teach the interested groups how to conduct the CSR activities (Arzamendia et al., 2014; Romero et al., 2017; Cowan, 2019, vicam.org.ar accessed June 2020). This was the starting point of the second controversy.

Neighboring rural livelihoods in Jujuy demanded to develop their own CSR understandings in line with their traditional knowledge (Romero et al., 2017). This was answered by a group of researchers from INTA and local government officials, who from the start used a Participatory Action Research (PAR) approach, which incorporated community empirical knowledge of rural livelihoods. This resulted in a bottom-up collective construction of understanding, which was highly valued as "it meant working together." The process aimed to achieve a flexible CSR protocol adapted to local socio-ecological conditions and allow a learning cycle that positively modifies the environments that affect it (Romero et al., 2017).

As of 2012, the communities of Yavi in Jujuy initiated workshops. They aimed to exchange local traditional knowledge, adaptive management, and scientific knowledge in relation to vicugna administration, conservation, and fiber commerce trade (Romero et al., 2017). The INTA group identified controversies in the communities. Initially, there was a controversy within the residents. One group considered vicugnas as a nuisance, as the population had increased the competition with domestic animals caused economic loss. The other group stated that vicugnas are "sacred creatures," belonging to the Pachamama and should be unavailable for man to benefit from. This was resolved partially after the CSR experience. Members of each community assumed responsibility for taking care of vicugnas in their territory and expressed interest in the sustainable use of the species. The management committee has been endorsed by community assembly formed from Law $\mathrm{N}^{\circ} 5634$. They set rules like caring for the vicugna meanings that no one should mistreat them, prevent attacks by dogs, and alert of poachers. Some community groups chose to eliminate fences from waterholes to facilitate access to vicuñas. Likewise, some community groups decided to reserve part of the community grassland area for exclusive grazing of vicugnas (Romero et al., 2017; Cowan, 2019).

Vicugnas raw products from captive breeding and CSR sources are to an export company. However, disputes on property rights within the communities and with enforcement authorities have delayed selling fiber (Vilá et al., 2010; Wawrzyk, 2014). For similar reasons, although there is a nearby spinning mill, local development of innovative products is incipient, and the distribution of benefits is unclear.

\section{Transhumance Creole Goats in the High Mountains of Neuquen}

The Creole Goats transhumant system originally managed a broader territory than today. Restrictions caused by the political partition between Chile and Argentina (1850) and provincial division disconnecting in 1955 Mendoza from Neuquén. Modern mining, land grabbing, and fencing has reduced grazing areas. Restrictions on the movement on public lands have economic 
and social integration impacts on these subsistence rural livelihoods (Bendini et al., 2004).

The government vertex implemented provincial policies and regulations that have evolved over the years. In the 1970s, the government passed legislation banning transhumant pastoralism due to concerns around overgrazing and subsequent depletion of resources and environmental threat. This perception continued in the 1980s and promoted two top-down strategies to develop rural livelihoods. One was to convert the transhumance system to that of afforestation with exotic species. The aim was to offer labor through government employment replacing selfemployment of the transhumant system (Pérez Centeno, 2001; Bendini et al., 2004). Provincial Government commissioned feasibility studies for Mohair, dairy cows, and goat production. They introduced transboundary breeds such as Angora, Anglo Nubian, and Toggenburg goats, as well as Jersey and Holstein dairy cows. During the end of the 1990s, in response to local demands, the provincial government started providing economic support for research and development projects (R\&D). Several programs received funding from the provincial state, with the aim of improving commercialization opportunities. Protective Denomination of Origin (PDO) seal for Creole Chivito Neuquino meat (López Raggi et al., 2010), and a market for combed Cashmere arose as a way to optimize local income and achieve fairer trade opportunities.

This sequence of development strategies led to a controversy at the scientific vertex about the modes of production for the region. One group set out with the bottom-up ideas to recognize the adaptability and resistance of local breeds and improve them with the active participation of the rural livelihood subsistence and niche marketing (Pérez Centeno, 2001; López Raggi et al., 2010). INTA through researchers and local and provincial extension services, focused on endogenous development. This group developed a formal on site scientific/technological knowledge. Later research concerned the characterization of the local Creole Neuquen Goat breed, which included health reproduction and traditional system. The growing number of publications (Robles et al., 1999; Lanari, 2004; Perez Centeno, 2007; Zimerman et al., 2007; Cueto, 2008; Maurino et al., 2008; López Raggi et al., 2010; Easdale et al., 2016) proves this.

Regarding controversies in the scientific vertex: other groups promoted another strategy for cashmere development The CONICET and Universidad de Cordoba researchers aimed at maximizing raw fiber production. They promoted electric shearing for the international brokers as opposed to combing Cashmere and elaborating goods locally (Frank et al., 2018).

The rural livelihood vertex identifies themselves as "crianceros." Transhumance is adapted to mountainous environments and adverse climatic conditions marked by seasonality. Additionally, herd movements allow an efficient territorial occupation and use of resources (Easdale and Aguiar, 2018). A social network strongly rooted in traditions, where members carry out diverse functions, sustains the system. The "castronerias" are an example of the social construction of these networks. Typical practice is to separate bucks from the does during the off-season to avoid winter calving and to ease the movements of the herds. Buck Keepers gather bucks from different owners and herds, generally in inaccessible places, mostly on public land. This practice is a key component of the annual production cycle, allowing synchronization of mating through "bucks effect" when males and does come together, and therefore strict seasonality. The Law (Provincial Law about Land Use $\mathrm{N}^{\circ}$ 682) considers them illegal since it states that "crianceros" may run only their own stock on public land (Lanari, 2004; Lanari et al., 2007; Moronta et al., 2017). The transhumance pastoral system maintains several species, although the Neuquén Creole Goat is the one with the broadest representation and cultural importance.

The system possesses traditional knowledge that sustains its resilience and ability to adapt to the challenging environment of the southern Andes. "Crianceros" resisted attacks to their livelihoods, causing social resistance that still exists today (Easdale et al., 2019). However, development of formal scientific/technological knowledge caused changes in the way that the government vertex (laws, resolutions, subsidies, etc.) valued this system. The "Crianceros" have also changed. They proudly manifest and perceive themselves as such throughout the endogenous development of PDO (Pérez Centeno et al., 2007).

Several steps were undertaken to develop innovative products. By the development of the PDO in 2010, the commercialization systems improved by providing a more structured access to market. The installation of a spinning mill in Chos Malal in 2013 helped to develop a small-scale local textile industry and handicrafts (Maurino, 2020). Environmental transformations, urbanization and cultural changes are drivers of change and threaten the sustainability of the system (Easdale and Domptail, 2014).

Community-based programs or Biocultural Protocols can offer a framework and a first step for in situ conservation projects for animal genetic resources, making clear that the ownership is with the communities, as well as community owned and driven processes (FAO, 2007; Swiderska et al., 2012; Haile et al., 2020). This transhumance system has a close connection between communities and their Creole goat breed and has shown adaptations to environmental changes. To generate socioeconomic benefits in a future scenario, community-based programs should focus on genetics, grazing, legal instruments, and locally developed products using appropriate biocultural protocols. Tensions within the scientific vertex evolve to conflicts when advocating for different production systems (Easdale and Aguiar, 2018), thereby challenging the evolution of new products in the system. Biocultural protocols may help find pathways to get around environmental transformations, urbanization and cultural changes are drivers of change and threaten the sustainability of the system.

\section{Wool Sheep and Guanacos in the Patagonian Province of Santa Cruz}

Desertification represents a worldwide problem as reflected in the UN-Convention to combat Desertification. Defined as "land degradation in arid, semi-arid and dry sub-humid areas resulting from various elements, including climatic variations 
and human activities. The cause of this problem is a complex interaction between physical, biological, political, social, cultural, and economic factors (UNCCD, Article 1, 1994). These complex interactions can be seen in Santa Cruz. The historical production system was wool from Merino and Corriedale breeds, and more recently mutton on private lands. The three vertices analyzed here are aware of overgrazing problems caused by this monoculture production system.

To analyze this case study, the target will be on the National Law $\mathrm{N}^{\circ}$ 25.422/01 for "The recovery of sheep husbandry in Patagonia." It is likewise necessary to look into the Provincial Law 3039/08 (subordinate to National Law $N^{\circ} 22421$ ) that established the Provincial Program of Sustainable Management of Guanaco. The enforcement authority for these laws is the Consejo Agrario Provincial of Santa Cruz (CAP).

These two laws, National Law $\mathrm{N}^{\circ}$ 25.422/01 and Provincial Law 3039/08 (subordinate to National Law $\mathrm{N}^{\circ} 22421$ ), are legal instruments that provide an opportunity to observe controversies and tensions in regional development policies as they are under different Ministeries, the MAGyP and MADS, respectively. Throughout the drafting of these instruments, actors from the three vertices mobilized their resources of power, within the rural livelihood unions and individually. These unions and individuals arranged meetings with the MADS and MAGyP authorities, as well as CAP, in a power struggle between national and provincial jurisdictions. Both instruments initially aimed to: (i) replace national enforcement authority by a collegiate body that includes provincial and rural livelihood representatives; (ii) access to funds from Law 25.422/01 limited to sheep producers.

INTA is responsible for providing research to Law 25244 and Law 224221. MAGyP authority makes decisions based on the research results of INTA and CAP. However, MADS makes management decisions mainly based on the opinions of CONICET researchers.

Scientists of this controversial space share a common ground about the importance of conservation of grasslands. Both assume a possibility that stocking rates (domestic and native herbivores) can be managed around some form of forage equilibrium. They also assume grazing of wild and domestic herbivores is additive and that the species compete for the forage. The focus of the controversy lies around where this equilibrium should be in relation to stocking rates (Marino and Rodriguez, 2018; Oliva et al., 2019; Marino et al., 2020).

The internal common ground of INTA researchers is the belief that natural resources need to be actively managed to produce marketable assets for rural livelihoods and urban society. The CONICET believe wild herbivores should occupy grasslands without domestic animals, because they believe that livestock keepers producers always overstock, resulting in land degradation. They advocate for land sparing because grazing management affects guanaco populations and considers tourism as an alternative revenue source for the rural livelihoods profits (Nabte et al., 2013; Marino and Rodríguez, 2018).

The most abundant population of guanacos is in continental Patagonia. A survey in 2001 estimated 220,000 for the province of Santa Cruz. In 2013 the number of guanacos were estimated to be $1,350,000$, representing $65 \%$ of the Patagonian population and an annual growth rate between 10 and 15\% (Amaya et al., 2001; Manero et al., 2013; Bay Gavuzzo et al., 2015; Travaini et al., 2015). This rebound of guanacos population drew public attention and led to further controversy among the three vertices. Santa Cruz evolved into the classic arena of conservationproduction conflict as rural livelihoods use arguments of this controversy to claim economic losses.

The rural livelihoods endured three catastrophic events that followed each other in the mid-nineties. The environment was adversely affected by convergent drivers in the 1990s. These were a sequence of prolonged periods of drought aggravating desertification, president Menem's administration and economic policy, and the eruption of the Hudson volcano in 1991 (Wilson et al., 2011; Andrade, 2012; Taraborrelli and Pena, 2017). The eruption produced $4.3 \mathrm{~km} 3$ volume of tephra deposits spreading ashes over 120,000 km2 (Scasso et al., 1994; Kratzmann et al., 2008, 2010). Following tephra fall, around 1 million domestic animals died of starvation and waterhole contamination with ashes producing dehydration, blindness, teeth erosion, and also human health problems (Wilson et al., 2011). This scenario caused de-stocking and abandonment of farms (Wilson et al., 2011; Andrade, 2012; Taraborrelli and Pena, 2017) and consequently should have alleviated grazing pressure.

In the aftermath of these events, the rural livelihoods through the Federation of Agricultural Institutions of Santa Cruz reported an increase of guanaco's population between 2004 and 2014, causing additional deterioration of grasslands (Andrade, 2002; Wilson et al., 2011; Taraborrelli and Pena, 2017). Leaders advocated the idea to cull guanacos for meat. This would help to balance the overgrazing problem and provide jobs and equity to rural livelihoods. However, this meant developing a novel product, with accompanying laws and rules.

Santa Cruz currently supports two strategies for obtaining novel products. Farmers advocate for culling guanacos for meat and a mixed management to compensate for diminished carrying capacity. Conservationists advocate for rewilding by land sparing. However, both need to solve issues around key monitoring activities of results. Culling guanacos needs a very transparent socioecological monitoring system. Provincial authorities enacted a law that temporarily stops new protected natural areas. They demand an updated inventory of the agricultural and non-agricultural establishments, properties, and public and private lands in the rural area of the province of Santa Cruz.

\section{DISCUSSION AND CONCLUSIONS}

Sustainable use controversies of rural areas are complex because they exist in interdisciplinary and inter-institutional environments. They are about decision-making and access needs to lobbying resources. The three case studies discussed herein have similarities and differences in their focus and common grounds of the controversial spaces (Table 1). They create networks of relationships and bonds leading to intermittent results. Simultaneously, differences in common ground evolve causing conflicts. Questions of for whom and who should 
perform research and decision-making in communities: the rural livelihoods? The state? Researchers? Each case study has particularities and styles.

Researchers have a common ground, with the end goal of the sustainable use of vicugna and guanacos. Additionally, for the Creole goat case study, the common ground is that this breed can produce Cashmere fine fibers. However, in the three case studies common ground differs among research groups. The precautionary principle, which types of products, and how they are obtained, represent the pathways to conflicts because they contain political beliefs and networks forging opposing coalitions.

Political beliefs and traditions, as well as individual educational experiences define how the extension of experiences are approached. Top down or bottom-up experiences hold distinct epistemological and research consequences and they affect rural livelihoods in various ways. The processes of the three cases have been mixed, as they dynamically change over time. For the three rural livelihoods, meaningful regulations should be endogenous social constructions. The government and the opposed groups of the science vertices recognize the right of indigenous communities to their genetic resources in accordance to the Nagoya Treaty. In the Puna case, this appears to contradict the precautionary principle and the fauna legislation that grants the rights to the provinces. The controversy over genetic bottlenecks in both wild camelid populations faded as numbers increased and some data were available.

Different PAR methodologies in the three case studies provide opportunities to promote endogenous processes allowing a range of appropriate procedures. They could be practiced to surface the issues that seem to provide common ground but are not, thereby helping respect cultural values among and between stakeholders. Regardless of the method employed, it must produce a virtuous cycle that entails reflection, learning, and adaptation, which is facilitated by a communication strategy involving the data obtained throughout the process. This can increase transparency and enhances a common ground of trust in the social construction process.

Several programs received funds from the provincial state. The aim was to improve commercialization opportunities by creating a Protected Denomination of Origin (PDO) seal for meat from Creole Chivito Neuquino (López Raggi et al., 2010). Small deharing and spinning mills to develop a market for vicugna, Cashmere and guanaco's fiber are presently available near the production areas. The two vicugna groups have achieved little progress on marketing raw or different stages of processed products. Only one slaughter-house is permitted to collect and export the culled guanacos meat. As the program is recent, little data exist about how rural livelihoods market the product and culling effect. Access to the markets is still a problem to the rural livelihoods for the three case studies as they are remote from commercial centers, transportation, and communication (Figure 1).

Space and time scales are different for each vertex. The rural livelihood timescale occupies three generations and a variable distance between its animals and the nearest town. Researcher's timescales depend on project's lifespan or their interest in their professional life (i.e., three to maximum 40 years). Their landscapes run between their institution, the field of research, and global contacts. Theoretical governments' turnover rate occurs every 4 years, therefore their timescale is short and survival depends on power of coalitions. Their landscape is contained in the province and connections to the central government. Consequently, networks and identities may change over these different life courses. Similarly, life histories of products and marketing strategies change. The outcomes are tensions and disputes that challenge the ability to attain the sustainability goals initially set by each group. Moments of success are followed by moments of destruction. These depend on the type of alliances achieved and on transforming the processes in the hands of few actors or leaders. Amplifying responsibilities for community processes appropriated by as many players as possible, may represent a future strategy of sustainability.

Following Nudler's (2004), Voß and Bornemann (2011), Hill et al. (2013) controversial spaces may offer leverage points by reframing the controversies and adding value to negative results. These experiences were conspicuously absent from the literature. A long-term joint monitoring of these experiences would also help to leverage controversy to enrich future sustainability. As is common with wicked problems, there is no unique answer to the three case studies analyzed here and this manuscript has created more questions than solutions. However, the case studies do have overlapping solutions. For example, long-term multispecies grazing opportunities are available for the three case studies. Ultimately, it depends on how actors in the vertices can acquire flexibility in their common ground to face catastrophic events.

Public policies have evolved into elements of struggle for all engaged actors. Policies have altered the structure and the way of approaching programs offered to rural livelihoods in the provinces. In the three case studies, participants began making their requests for legal status of land tenure, use of territorial spaces, and appropriate technologies, which translated into strengthening the organization of livelihoods. However, cultural diversity and cohesion also suffer erosion in the adaptation process (Bendini et al., 2004; Walter et al., 2007; Borghini, 2010).

The scientific and technical teams fulfilled a role that began to drive the different sector interests according to their visions and epistemologies, which also evolve over time. The dynamics of the players in these state policies allows us to perceive the state as an actor that is neither monolithic nor homogeneous. Multidirectional and often contradictory thought processes are in competition for resources between institutions and for the support from society, at a given historical moment.

A difficulty to assess progress of programs is the absence of shared quality information and data among all actors. This lack of trust among actors delays learning and adjusting as indicated by the continuous evaluation of outcomes. There is a need for a system that shares results within government, the science community, and rural livelihoods, containing and acknowledging controversies (bottom up and base down, etc.). The system included in the construction and development of the programs should 
help to build trust and help learn and adapt according to ongoing results.

\section{DATA AVAILABILITY STATEMENT}

The original contributions presented in the study are included in the article/Supplementary Material, further inquiries can be directed to the corresponding author/s.

\section{ETHICS STATEMENT}

Ethical review and approval was not required for the study on human participants in accordance with the local legislation and institutional requirements. Written informed consent for participation was not required for this study in accordance with the national legislation and the institutional requirements. Ethical review and approval was not required for the animal study because We are using published data and no type of experiment was conducted.

\section{REFERENCES}

Amaya, J. N., von Thungen, J., and De Lamo, D. A. (2001). Densidad de guanacos (Lama guanicoe) en la Patagonia. Julio: INTA- GTZ-TÔB. doi: 10.13140/RG.2.1.3352.6648

Andrade, L. (2002). Territorio y ganadería en la Patagonia Argentina: desertificación y rentabilidad en la Meseta Central de Santa Cruz. Economía, Sociedad y Territorio. El Colegio Mexiquense, A. C. Toluca, México.

Andrade, L. (2012). Producción y ambiente en la Meseta Central de Santa Cruz, Patagonia austral en Argentina: desencadenantes e impacto de la desertificación. En Ambiente y Desarrollo 16, 73-92. doi: 10.22136/est002002341

Anello, M., Daverio, M. S., Romero, F., Rigalt, M. B., Silbestro, L., VidalRioja, F., et al. (2016). Genetic diversity and conservation status of managed vicuña (Vicugna vicugna) populations in Argentina. Genetica 144, 85-97. doi: 10.1007/s10709-015-9880-Z

Arzamendia, Y., Baldo, J., Rojo, V., and Samec y Bibiana Vilá, C. (2014). Manejo de vicuñas silvestres en Santa Catalina, Jujuy: investigadores y pobladores en búsqueda de la sustentabilidad y el buen vivir. Cuadernos del Instituto Nacional de Antropología y Pensamiento Latinoamericano - Series Especiales $\mathrm{N}^{\circ} 2$ $1,8-23$.

Arzamendia, Y., Maidana, R., Vilá B., and Bonacic, C. (2008). "Wild vicuñas management in Cieneguillas, Jujuy (Argentina)," in South American Camelids Research, eds E. Frank, M. Antonini, and O. Toro (The Netherlands: Wageningen Academic Publishers), 139-146.

Bay Gavuzzo, A., Gaspero, P., Bernardos, J., Pedrana, J., de Lamo, D., and von Thüngen, J. (2015). Distribución y densidad de guanacos (Lama guanicoe) en la Patagonia. Informe de relevamiento 2014-2015. Ediciones INTA. E-Book.

Bendini, M., Tsakoumagkos, P., and Nogues, C. (2004). "Los crianceros trashumantes del Neuquén," in Crianceros y chacareros en la Patagonia, eds M. Bendini, and C. Alemany (Buenos Aires, Argentina: La Colmena), 23-39.

Bisigato, A. J., and Bertiller, M. B. (1997). Grazing effects on patchy dryland vegetation in northern Patagonia. J. Arid Environ. 36, 639-653. doi: 10.1006/jare.1996.0247

Bolcovik, M. L., and Ramadori, D. (2006). "Manejo de Fauna Silvestre en Argentina," in Programas de Uso Sustentable, eds M. L. Bolkovic and D. Ramadori (Ministerio de Salud y Ambiente de la Nacion), 176.

Bonacic, C., and Gimpel, J. (2003). "Sustainable Use of the Vicuna: A Critical Analysis and the MACS Project," in Conserving Biodiversity in Arid Regions, eds J. Lemons, R. Victor, and D. Schaffer, (Boston, MA: Springer), 345-354.

\section{AUTHOR CONTRIBUTIONS}

JT conceived the idea. ML provided information on the cases. EM provided information and analysis of the legal aspects of the cases. JT and ML wrote and revised the paper.

\section{ACKNOWLEDGMENTS}

We would like to thank Simone de Hek for encouraging us to write this article and push us out of our comfort area to discuss this topic. Lorraine Green and Mattew Beck helped us by improving our English writing.

\section{SUPPLEMENTARY MATERIAL}

The Supplementary Material for this article can be found online at: https://www.frontiersin.org/articles/10.3389/fsufs. 2021.550821/full\#supplementary-material

Borghini, N. (2010). Tenencia precaria de la tierra y políticas públicas en Jujuy, Argentina. Un análisis de los vínculos entre provincia, nación y pueblos originarios. Apuntes. Rev. Ciencias Soc. 129-155. doi: 10.21678/apuntes.67.611

Casey, C. S., Orozco-ter Wengel, P., Yaya, K., Kadwell, M., Fernández, M., Marín, J. C., et al. (2018). Comparing genetic diversity and demographic history in co-distributed wild South American camelids. Heredity 121, 387-400. doi: 10.1038/s41437-018-0120-z

Cowan Ros, C., and Nussbaumer, B. (2013). "Comunidad indígena": (des)encuentros de sentidos entre miembros de la institucionalidad pública $y$ de comunidades aborígenes del departamento de Yavi, provincia de Jujuy (Cuadernos de Antropología Social N ${ }^{\circ} 37$ ), 109-137.

Cowan, R. (2019). Manejo comunitario de vicuñas en silvestría como gestión de un bien común en Yavi, Argentina. Braz. J. Develop. 5, 9705-9732. doi: $10.34117 /$ bjdv5n7-148

Cueto, M. I. (2008). Caracterización Reproductiva de las Cabras Criollas Neuquinas. Tesis Doctoral. Fac. Biología (Centro Regional Universitario Bariloche. Univ. Nacional del Comahue), 284.

Easdale, M. H., and Aguiar, M. R. (2018). From traditional knowledge to novel adaptations of transhumant pastoralists the in face of new challenges in North Patagonia. J. Rur. Stud. 63, 65-73. doi: 10.1016/j.jrurstud.2018.09.001

Easdale, M. H., Aguiar, M. R., and Paz, R. (2016). A social-ecological network analysis of Argentinean Andes transhumant pastoralism. Reg. Environ. Change 16, 2243-2252. doi: 10.1007/s10113-015-0917-8

Easdale, M. H., and Domptail, S. E. (2014). Fate can be changed! Arid rangelands in a globalizing world- a complementary co-evolutionary perspective on the current 'desert syndrome'. J. Arid Environ. 100-101, 52-62. doi: 10.1016/j.jaridenv.2013.10.009

Easdale, M. H., Pérez León, N., and Aguiar, M. R. (2019). Strains in sustainability debates: traditional ecological knowledge and western science through the lens of extension agents in a pastoral region. Rur. Sociol. 85, 57-84. doi: $10.1111 /$ ruso. 12268

Etzkowitz, H., and Leydesdorff, L. (2000). The dynamics of innovation: from National Systems and "Mode2" to a Triple Helix of university-industry-government relations. Res. Policy 29, 109-123. doi: 10.1016/S0048-7333(99)00055-4

Fairweather, J. R. (2010). Farmer models of socio-ecologic systems: application of causal mapping across multiple locations. Ecol. Model. 221, 555-562. doi: 10.1016/j.ecolmodel.2009.10.026

Fairweather, J. R., and Hunt, L. M. (2011). Can farms map their farm system? Causal mapping and the sustainability of sheep/beef farms in New Zealand. Agric. Hum. Val. 28, 55-66. doi: 10.1007/s10460-009-9252-3 
FAO (2007). The State of the World's Animal Genetic Resources for Food and Agriculture. ed. Barbara Rischkowsky and Dafydd Pilling (Rome), 524.

Frank, E. N., Hick, M. V. H., Castillo, M. F., and Seghetti Frondizi, D. G. (2018). Determination of the optimal number of runs of dehairing in fibers of patagonian cashmere goats. J. Textile Eng. Fashion Technol. 4, 188-190. doi: 10.15406/jteft.2018.04.00144

Gaitán, J. J., Bran, D. E., Oliva, G. E., Aguiar, M. R., Buono, G. G., Ferrante, D., et al. (2018). Aridity and overgrazing have convergent effects on ecosystem structure and functioning in patagonian rangelands. Land Degrad. Develop. 29, 210-218. doi: $10.1002 /$ ldr.2694

García, C. L., Teicha, I., Gonzalez-Roglich, M., Federico Kindgard, A., Carlos Ravelo, A., Liniger, H. (2019). Land degradation assessment in the Argentinean Puna: comparing expert knowledge with satellite-derived information. Environ. Sci. Policy 91, 70-80. doi: 10.1016/j.envsci.2018.10.018

Haile, A., Getachew, T., Mirkena, T., Duguma, G., Gizaw, S., Wurzinger, M., et al. (2020). Community-based sheep breeding programs generated substantial genetic gains and socioeconomic benefits. Animal 1, 1362-1370. doi: $10.1017 / S 1751731120000269$

Hill, R., Halamish, E., Gordon, I. J., and Clark, M. (2013). The maturation of biodiversity as a global social-ecological issue and implications for future biodiversity science and policy. Futures 46, 41-49. doi: 10.1016/j.futures.2012.10.002

Hoffmann, R., Otte, R., Prado, K. C., Rios, and, F. P. D. (1983). El Manejo de la Vicuña Silvestre (GTZ, Eschborn), 705.

INDEC (2010). Censo Nacional de Población, Hogares y Viviendas 2010. Available online at: http://www.indec.gov.ar/censo2010/2010_ampliado_completo.pdf

Kratzmann, D. J., Carey, S., Scasso, R., and Naranjo, J. (2008). Compositional variations and magma mixing in the 1991 eruptions of Hudson volcano, Chile. Bull. Volcanol. 71, 419-439. doi: 10.1007/s00445-0080234-x

Kratzmann, D. J., Steven, N., Carey, F.ero, J., Scasso, R. A., and Naranjo, J.A. (2010). Simulations of tephra dispersal from the 1991 explosive eruptions of Hudson volcano, Chile. J. Volcanol. Geothermal. Res. 190, 337-352. doi: 10.1016/j.jvolgeores.2009.11.021

Kuhlmann, S., and Rip, A. (2019). "Next generation science policy and grand challenges," in Handbook on Science and Public Policy (Northampton, MA: Edward Elgar Publishers), 12-25.

Lacy, R. C. (1992). "The effects of inbreeding on isolated populations: are minimum viable population sizes predictable?," in Conservation Biology, eds P. L. Fiedler, and S. K. Jain (Boston, MA: Springer), 277-296. doi: 10.1007/978-1-4684-6426-9_11

Lanari, M. R. (2004). Variación y diferenciación genética y fenotípica de la Cabra Criolla Neuquina en relación con su sistema rural campesino. Tesis Doctoral. Fac. Biología (Centro Regional Universitario Bariloche. Univ. Nacional del Comahue), 234.

Lanari, M. R., Pérez Centeno, M. J., and Domingo, E. (2007). “The Neuquén criollo goat and its production system in Patagonia, Argentina," in People and Animals Traditional Livestock Keepers: Guardians of Domestic Animal Diversity, eds K. Tempelman and R. A. Cardellino (Rome: FAO), 7-15.

Lecuyer, L., White, R. M., Schmook, B., and Calmé, S. (2018). Building on common ground to address biodiversity conflicts and foster collaboration in environmental management. J. Environ. Manage. 220, 217-226. doi: 10.1016/j.jenvman.2018.05.014

León, R. J. C., and Aguiar, M. (1984). El deterioro por uso pasturil en estepas herbáceas patagónicas. Phytocoenologia 13, 181-196.

Longo, A., and Valdecantos, P, A. (2012). Marcadores moleculares y diversidad genética de vicuñas: aportes para la conservación y el manejo. X Congreso Internacional de Manejo de Fauna Silvestre en la Amazonía y Latinoamérica 51.

López Raggi, F., Pérez Centeno, M., Lanari, M. R., and von Thüngen, J. (2010). "Marketing Criollo goat meat under a protected designation of origin seal in Argentina," in Adding value to livestock diversity-Marketing to promote local breeds and improve livelihoods, eds LPP, LIFE Network, IUCN-WISP and FAO., FAO Animal prod. and health paper $\mathrm{N}^{\circ} 168$ (Rome: FAO), 73-80.

Manero, A., Dragnic, K., Clifton, G., and Vargas, P. (2013). Relevamiento de poblaciones de guanaco en la provincia de Santa Cruz. (UNPA Universidad Nacional de la Patagonia Austral (Unidad Académica Rio Gallegos, Rio Gallegos), 19.
Marino, A., and Rodríguez, V. (2018). On resource defense and sustainable grazing: forage use by territorial and non-territorial guanaco groups. J. Arid Environ. 152, 87-90. doi: 10.1016/j.jaridenv.2018. 01.014

Marino, A., Rodríguez, V., and Schroeder, N. M. (2020). Wild guanacos as scapegoat for continued overgrazing by livestock across southern Patagonia. J. Appl. Ecol. 57, 2393-2398. doi: 10.1111/1365-2664.13536

Maurino, J. (2020). Cosecha y Agregado de valor en fibra cashmere de Cabras Criollas Neuquinas. Tesis de Maestría en Producción de Rumiantes Menores (UN Comahue-Un Rosario- INTA), 77.

Maurino, M. J., Monacci, L., Lanari, M. R., Pérez Centeno, M. J., Sacchero, D., and Vázquez, A. (2008). Caracterización de la fibra Cashmere del Norte Neuquino in Memorias del IX Simposio Iberoamericano de Recursos Genéticos. Mar del Plata 2008, 457-460. Available online at: http://hdl.handle.net/20.500.12123/ 8000

Mazzonia, E., and Vazquez, M. (2009). "Desertification in Patagonia," in Developments in Earth Surface Processes, Vol. 13, ed E. M. Latrubesse (Elsevier), 351-377. doi: 10.1016/S0928-2025(08)10017-7

Moronta, M. N., Pérez, M. J., Lanari, M. R., Giovannini, N., Maurino, J., Mogni, A. J., and Mikuc, J. P. (2017). Relevamiento de castronerías en la provincia de Neuquén -Patagonia -Argentina. Actas Iberoamericanas de Conservación Animal 4, 243-246.

Nabte, M. J., Marino, A. I., Rodriiguez, M. V., Monjeau, A., Saba, S. L. (2013). Range management affects native ungulate populations in peninsula valdes, a world natural heritage. PLoS ONE 8:e55655. doi: 10.1371/journal.pone.0055655

Noy-Meir, I. (1973). Desert ecosystems: Environment and producers. Annual Rev. Ecol. Syst. 4, 25-51. doi: 10.1146/annurev.es.04.110173.000325

Nudler, O. (2004). Hacia un modelo de cambio conceptual: espacios controversiales y refocalización. Revista de Filosofía 29, 7-19.

Oliva, G., Paredes, P., Ferrante, D., Cepeda, C., and Rabinovich, J. (2019). Remotely sensed primary productivity shows that domestic and native herbivores combined are overgrazing Patagonia. J. App. Ecol. 56, 1575-1584. doi: 10.1111/1365-2664.13408

Orr, B. J., Cowie, A. L., Castillo Sanchez, V. M., Chasek, P., Crossman, N. D., Erlewein, A., et al. (2017). Scientific Conceptual Framework for Land Degradation Neutrality. A Report of the Science-Policy Interface. Bonn: United Nations Convention to Combat Desertification (UNCCD).

Pérez Centeno, M. (2001). Producción familiar trashumante e instituciones de desarrollo frente a las modificaciones territoriales Neuquen (Argentina). Université Toulouse - Le Mirail Ecole Nationale de Formation Agronomique Ecole Nationale Superieure Agronomique De Toulouse. Memorias DEA. 100.

Perez Centeno, M. (2007). Transformations des stratégies sociales et productives des éleveurs trashumants de la province de Neuquén et de leurs relations avec les interventions de développement. Tesis de Doctorado. Université Toulouse Le Mirail. INTA - INRA. 295.

Pérez Centeno, M., Lanari, M. R., Romero, P., Monacci, L., Zimerman, M., Barrionuevo, M., et al. (2007). Puesta en valor de un sistema tradicional y de sus recursos genéticos mediante una Indicación Geográfica: El proceso de la Carne Caprina del Norte Neuquino en la Patagonia Argentina. Anim. Genet. Resour. 41, 17-24. doi: 10.1017/S1014233900002297

Petitpas, R., and Bonacic, C. (2019). Ontological politics of wildlife: local people Conservation Biologists and Guanacos. Conservat. Soc. 17, 250-257. doi: 10.4103/cs.cs_18_95

PRODESER (1997). Sistema regional de soporte de decisiones. Santa Cruz y Tierra del Fuego. INTA/GTZ. Buenos Aires).

Quiroga Mendiola, M. (2013). "Llueve sobre mojado. Transhumancia conceptual frente al pastoralismo alto andino," in La desigualdad? 'del desarrollo?: Controversias y disyuntivas del desarrollo rural en el norte argentino. ed M. Manzanal, M. Ponce - 2013 - Ediciones Ciccus.

Rendon Burgos, and Hugo, O. (2000). "Bolivian experience in the communal management of the vicuña," in Seminario Manejo Sustentable de la Vicuña y el Guanaco, eds P. Benito González, M. Fernando Bas Charif Tala G, and W. Agustín Iriarte (Santiago Chile. Ed EDITORES).

Robles, C. A., Lanari, M. R., Pérez Centeno, M., and Domingo, E. (1999). Relevamiento de Brucelosis y Artritis encefalitis en caprinos criollos de la provincia de Neuquén. Vet. Arg. 160, 740-746.

Rodriguez Zoya, L. G., and Rodriguez Zoya, P. G. (2014). The Controversial space of complex systems. Estudios de Filosofia 50, 103-129. 
Romero, S. R., Godoy Garraza, G., and Tolaba, M. V. (2017). "Identidad, organización y territorio. Conservación y manejo de vicuñas por comunidades aborígenes de la Puna de Jujuy," in Políticas públicas en la ruralidad argentina, eds M. M. Patrouilleau, W. F. Mioni, and C. I. Aranguren (Ediciones INTA, Libro digital. $1^{\text {a }}$ ed. - Buenos Aires), 185-206.

Sábato, J. (1975). El pensamiento latinoamericano en la problemática cienciatecnología-desarrollo-dependencia (Buenos Aires: Paido’s), 349.

Scasso, R. A., Corbella, H., and Tiberi, P. (1994). Sedimentological analysis of the tephra from the 12-15 August 1991 eruption of Hudson volcano. Bull. Volcanol. 56, 121-132.

Swiderska, K., Shrumm, H., Hiemstra, W., Oliva, M. J., Kohli, K., Jonas, H., et al. (2012). Biodiversity and Culture: Exploring Community Protocols, Rights and Consent. Special issue of Participatory Learning and Action, Vol. 65. Iied Publisher.

Taraborrelli, D., and Pena, S. (2017). "Ley Ovina en Patagonia (2001-2016): el proceso de la política pública," in Políticas públicas en la Ruralidad Argentina, eds M. M. Patrouilleau, W. F. Mioni, and C. I. Aranguren (Ediciones INTA, Libro digital. $1^{\text {a }}$ ed. - Buenos Aires), 207-234.

Travaini, A., Zapata, S. C., Bustamante, J., Pedrana, J., Zanón, J. I., and Rodríguez, A. (2015). Guanaco abundance and monitoring in Southern Patagonia: distance sampling reveals substantially greater numbers than previously reported. Zool. Stud. 54:23. doi: 10.1186/s40555-01 4-0097-0

UNCCD (1994). Text of the United Nations Convention to Combat Desertification. A/AC 241/27. Available online at: https://www.unccd.int/convention/aboutconvention. (accessed April 3, 2020).

Vanclay, F., Howden, P., Mesiti, L., Glyde, S. (2006). The social and intellectual construction of farming styles: testing Dutch ideas in Australian agriculture. Sociol. Rural. 46, 61-82. doi: 10.1111/j.1467-9523.2006.00404.x

Vila, B. (2002). La silvestria de las vicuñas, una característica esencial para su conservación. Ecol. Austral. 12, 79-82.

Vila, B., and Lichtenstein, G. (2006). "Manejo de vicuñas en la Argentina Experiencias en las provincias de Salta y Jujuy," in Manejo de Fauna Silvestre en Argentina. Programas de Uso Sustentable, eds M. L. Bolkovic and Y. D. Ramadori (Ministerio de Salud y Ambiente de la Nacion), 176.

Vilá, B., Wawrzyk, A., and Arzamendia, Y. (2010). El manejo de vicuñas silvestres (Vicugna vicugna) en Jujuy (Argentina): Un análisis de la experiencia del proyecto MACS, en Cieneguillas. Revista Latinoamericana de Conservación. Bogotá. Colombia. 1, 38-52.
Voß, J., and Bornemann, B. (2011). The politics of reflexive governance: challenges for designing adaptive management and transition management. Ecol. Soc. 16: 9. Available online at: http://www.ecologyandsociety.org/vol16/iss2/art9/ (accessed June 28, 2020).

Walter, A. I., Helgenberger, S., Wiek, A., and Scholz, R. W. (2007) Measuring societal effects of transdisciplinary research projects: design and application of an evaluation method. Eval. Program Plann. 30, 325-338. doi: 10.1016/j.evalprogplan.2007.08.002

Wawrzyk, A. C. (2014). “Desarrollo local y conservación de vicuñas silvestres en la puna jujeña: presente y futuro a partir de la experiencia de manejo de la localidad de Cieneguillas," in Espacialidades altoandinas. Nuevos aportes desde la Argentina:Interacciones con el "mundo de afuera"/Alejandro Benedetti... [et al.]; compilado por Alejandro Benedetti Jorge Tomasi. - 1a ed. - Ciudad Autónoma de Buenos Aires: Editorial de la Facultad de Filosofía y Letras Universidad de Buenos Aires 1:352.

Wheeler, J. C., Chikhi, L., and Bruford, M. W. (2006). "Genetic analysis of the origins of domestic South American camelids," in Documenting Domestication. New Genetic and Archaeological Paradigms, eds M. A. Zeder, D. G. Bradley, E. Emshwiller, and B. D. Smith (Berkeley: University of California Press), 329-341.

Wilson, T., Cole, J., Cronin, S., Stewart, C., and Johnston, D. (2011). Impacts on agriculture following the 1991 eruption of Vulcan Hudson, Patagonia: lessons for recovery. Nat. Hazards 57, 185-212. doi: 10.1007/s11069-010-9 604-8

Zimerman, M., Domingo, E., and Lanari, M. R. (2007). Carcass characteristics of “NEUQUEN CRIOLLO KIDS” in Patagonia, Argentina. Meat. Sci. 79, 453-45. doi: 10.1016/j.meatsci.2007.12.007

Conflict of Interest: The authors declare that the research was conducted in the absence of any commercial or financial relationships that could be construed as a potential conflict of interest.

Copyright (c) 2021 von Thungen, Martin and Lanari. This is an open-access article distributed under the terms of the Creative Commons Attribution License (CC BY). The use, distribution or reproduction in other forums is permitted, provided the original author(s) and the copyright owner(s) are credited and that the original publication in this journal is cited, in accordance with accepted academic practice. No use, distribution or reproduction is permitted which does not comply with these terms. 